\title{
Pregnancy Diagnosis by the Ultrasonographical Device and Observation of Fetal Growth in the Squirrel Monkey (Saimiri sciureus)
}

\author{
Hayato NARITA, Masaaki HAMANO and Fumiaki CHO*
}

\begin{abstract}
The Corporation for Production and Research of Laboratory Primates, and *Tsukuba Primate Center for Medical Science, The National Institute of Health, Hachimandai, Tsukuba-shi, Ibaraki-ken, 305, Japan.
\end{abstract}

(Received 22 December 1987/Accepted 13 May 1988)

\begin{abstract}
This paper describes usefullness of the ultrasonographical device (USD) for the diagnosis of pregnancy and the observation of fetal growth in the squirrel monkeys (Saimiri sciureus) conceived under group breeding conditions. Pregnancy was diagnosed on the basis of the detection of gestational sac (GS) in the uterus. The GS was first detected $127 \pm 10$ days before delivery. The heart beat of embryo was detected around 114 days before delivery. It was able to judge conditions of fetal growth by measuring the size of GS and the biparietal diameter. No difference in uterine size between nonpregnant and pregnant animals was observed 135 days before delivery.
\end{abstract}

\section{超音波診断装置によるリスザルの妊娠診断と胎仔の発育観察}

\author{
成田勇人·浜野政章·長＼cjkstart文昭* \\ 社団法人予防衛生協会 \\ *国立予研筑波医学実験用霊長類センター
}

\begin{abstract}
実験動物としてのサル類の繁殖・育成を効率よく進め て行くうえで早期妊娠診断法の確立は重要な課題である。 当センターでは, カニクイザルの妊娠診断を子宮触䧐法 により交配後 5 週目に [2], また, 血中の絨毛性生殖腺 刺激ホルモンの測定により交配後 3 ないし 4 週目に [6] 実施している。また, 最近超音波揨断装置 (Ultrasonographical Device, USD) によって胎秢17〜23日の間に 妊娠診断が可能であることを報告した $[1]$ 。この USD 法は繁殖の現場での操作の容易さからあ優れた方法であ る。そてで, USD 法をカニクイザルよりも小型のサル の一種で実験動物として繁殖生理学等の分野で有用性の 高いリスザルの妊娠診断に適用することを試みた。リス
\end{abstract}

ザルは，カニクイザルでみられるような月経周期は認め られないので, それによる交配適期の推定は不可能であ る。そして，簡便な交配商期の推定法は未だ確立されて いない。このようなととから, リスザルの交配には雌雄 の長期同居方式を採用するととが多い [3，4]。その為, 特に早期妊娠診断法の確立が必要である。さらに, 雌雄 長期同居方式では妊娠日を特定できないために，胎仔の 成長過程を正確に把握することや妊娠個体を適切に管理 することは容易ではない。

本報告は, リスザルでの早期妊娠診断の為に USD 法 を適用した結果を述べるものである。な怙，合わせて USD 法によりリスザルの胎仔の発育を観察した結果に 
ついて報告する。

\section{材料及び方法}

I 動物と交配方式：対象とした動物は，ボリビア原 産の野生由来の雌雄の成熟リスザル(Saimiri sciureus) 雄15頭, 雌40頭である。動物は, 入荷後 11 週間の検疫期 間を経て筑波医学実験用霊長類センターの繁殖コロニー において種ザルとして使用されているあのである。交配 は, 雄 1 頭と雌 $3 \sim 5$ 頭との長期同居方式によった。本 観察期間中に妊娠した個体数は24頭であり，それらはす べて正常分娩した。

II 飼育条件：飼育室の照明条件は, 白色蛍光灯と植 物用蛍光灯ホモルクス (ナショナル製) あるいは, サン ラインビューティー (日立製) の 5 時点灯, 19時消灯の 14時間明10時間暗である。空調条件としては, 100\%の 新鮮空気を 1 時間に 12 回換気し, $25 \pm 2{ }^{\circ} \mathrm{C}$ の温度と $60 \pm$ $10 \%$ 湿度を保持した。飼料は 1 頭当り, 午前にリンゴ ・ミカン各50g を給与し, 午後にはウズラの卵 1 ケと固 型飼料（オリエンタル酵母製 A S 型） $50 \mathrm{~g}$ を水で膨潤さ せて与えた。飲水は, 自動給水装置により自由に摄取さ せた。収容ケージは, ステンレススチール製金網ケージ で $45 \mathrm{~cm}$ (幅) $\times 60 \mathrm{~cm}$ (奥行) $\times 60 \mathrm{~cm}$ (高さ) のあのを使用 した。雌雄の長期同居時は, このケージを 2 台むしくは 4 台連結したものを使用し, 妊娠が判明してからは個別 飼育とした。

III 妊娠診断及び計測：妊娠診断及び子宮・胎仔の計 測は, 超音波診断装置（アロカ社製 SSD-125 電子リニ ア型, $7.5 \mathrm{MHz}$ 探触子) を用いて無麻酔下で行った。
子宮内に妊娠のう（Gestational Sac, GS) が認められ た場合妊娠と判断し, その後さらに胎芽内の心拍動を確 認した。妊娠診断は, リスザルの交尾期 (12月より翌年 の 6 月まで）には週 1 回行い，それ以外の時期は 2 週每 に行った。妊娠と判定されてから分娩までの間, 週に 1 回もしくは 2 週に 1 回, 以下のごとく計測を実施した。 すなわち, 妊娠早期には子宮及び GS の長径と短径であ り, 妊娠中期・後期（分婏前 110 日以降）には胎仔の頭 部大横径 (Biparietal Diameter, BPD) である。また, 対照として35頭の非妊娠動物の子宮の大きさを計測した。

IV USD そよる計測值の信頼性：USD そよる BPD の計測值の信頼性を見るために出生前2.6日土2.4日（平 均 \pm S.D.) の胎仔 (雌雄各 4 頭) を計測した。同一個体 を出生直後（24時間以内）に無麻酔下で保定し, ノギス を用いて BPD を計測した。

$\mathrm{V}$ 統計学的処理：計測項目のうち GS の長径及び短 径は対数変換 (自然対数) し，その他の項目は計測值を そのまま用い，分婏前日数との対応を調へたた。S 及び 子宮の計測值については, 分婏前日数との相関係数も算 出した。また, 妊娠子宮の大きさの一次回帰式を求め非 妊娠時の子宮の大きさの平均值と比較した。USD によ る胎仔の BPD の計測值及びそれらの出生後の BPD の 計測值については, 対応のある $\mathrm{t}$-検定を施した。

成 績

GS が初めて検出できた時期は，分婏前127日 10 日で あった。この時期の GS は子宮内に米粓大の黒斑として 認められるが, その確認には熟練を要した (Fig. 1)。
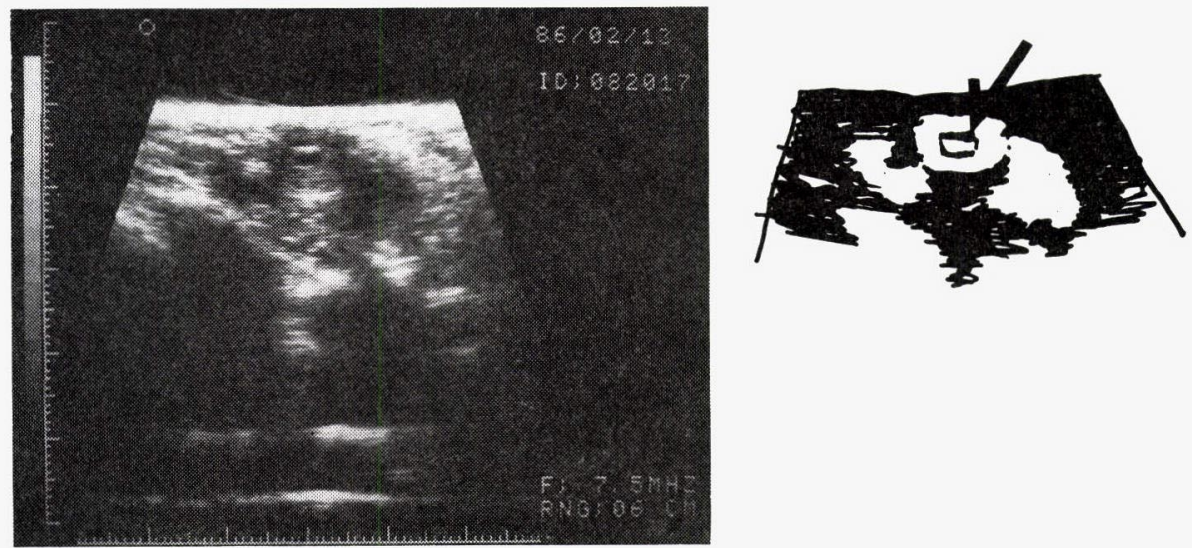

Fig. 1. An image of gestational sac (the arrow) detedted on the 140th day before delivery 

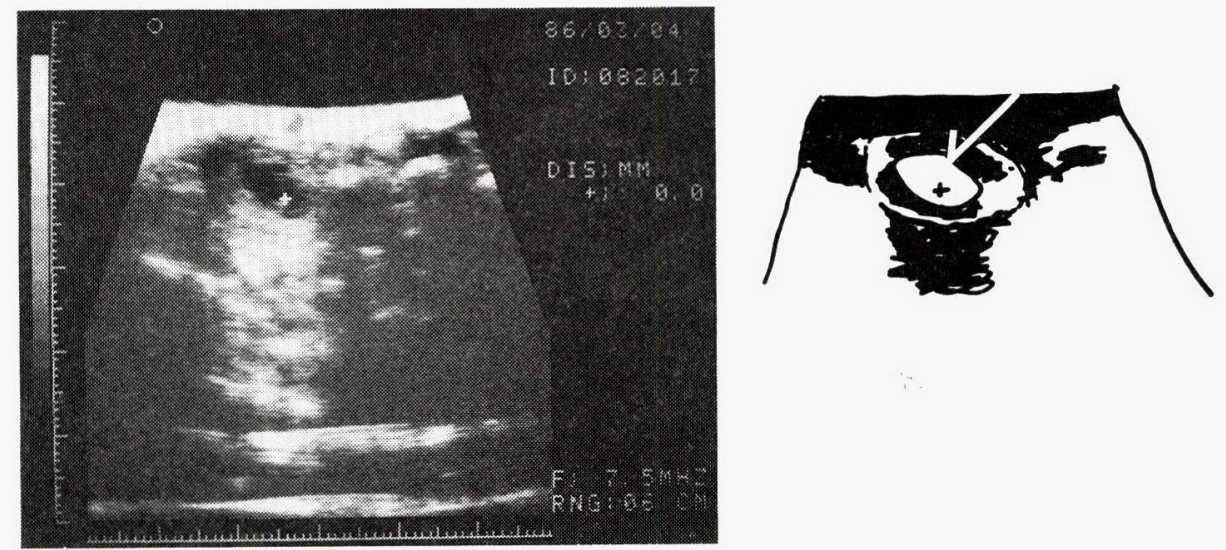

Fig. 2. An image of gestational sac (the arrow) detected on the 120th day before delivery
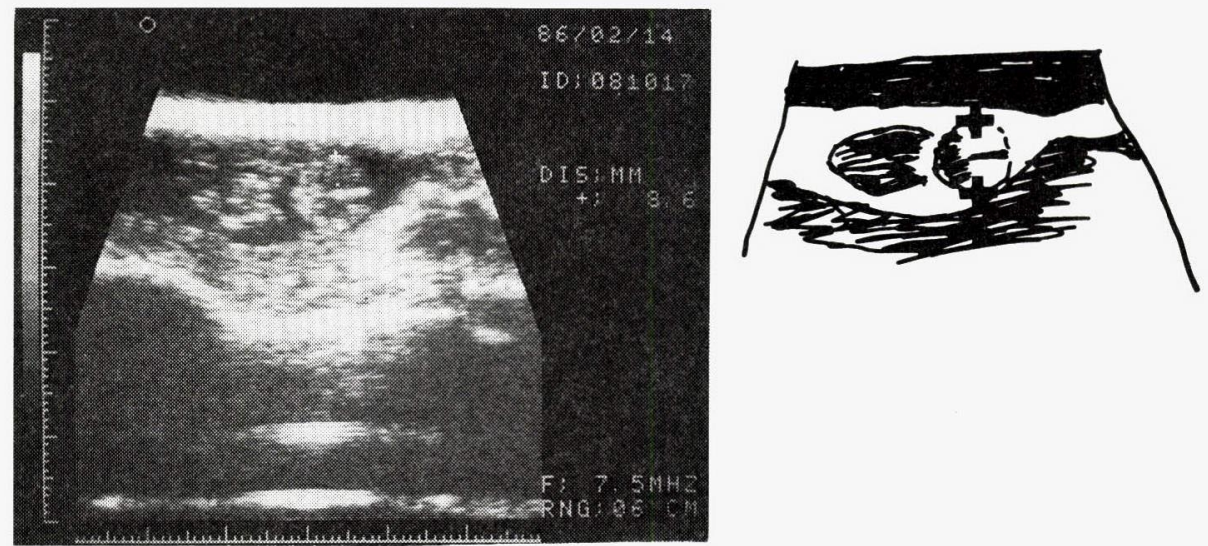

Fig. 3. An image of a fetus on the 95th day before delivery. Biparietal diameter of the fetus was indicated by the distance of two crosses $(8.6 \mathrm{~mm})$

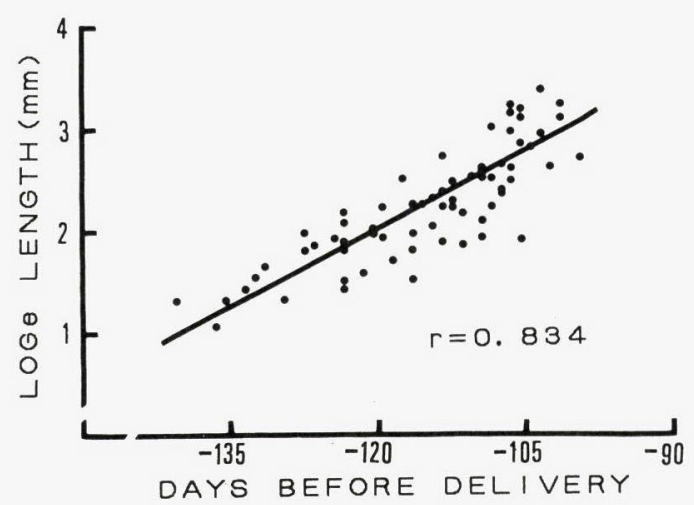

Fig. 4. Correlation between the natural logarithmic value of major axial length $(\mathrm{mm})$ of gestational $\mathrm{sac}$ and the number of day before delivery $(\mathrm{p}<$ 0. 01)

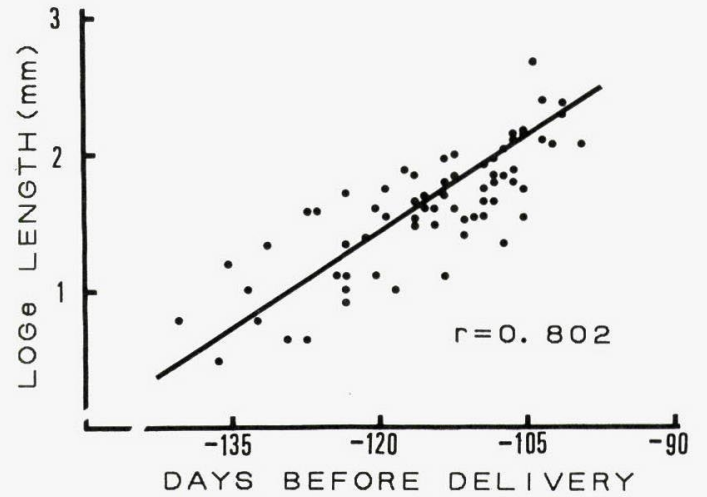

Fig. 5. Correlation between the natural logarithmic value of minor axial length (mm) of gestational sac and the number of day before delivery $(\mathrm{p}<$ 0. 01) 
しかし，それから約 2 週間後になると GS は明らかに大 きくなり比較的容易に識別できるようになった。また， 同じ頃には心拍動も確認できるようになった（Fig．2)。 さらに, それから約 1 週間たつと頭部及び体幹部の識別 あ可能となった。しかし，GS 及び子宮の全体像は撮影 不能となった (Fig. 3)。GS の長径及び短径の変化は Figs 4.5 の通りである。測定值の自然刘数值は, 分娩 前130日から100日までの期間で, 分婏前日数之有意な相 関が認められた。相関係数は長径では $0.834(\mathrm{p}<0.01)$ また, 短径では0.802（p<0.01）であった。他方, BPD の測定は分娩前 105 日ごろから行った。分娩前 105 日ご ろから分婏前30日ごろまでは頙著に増加したが, それ以

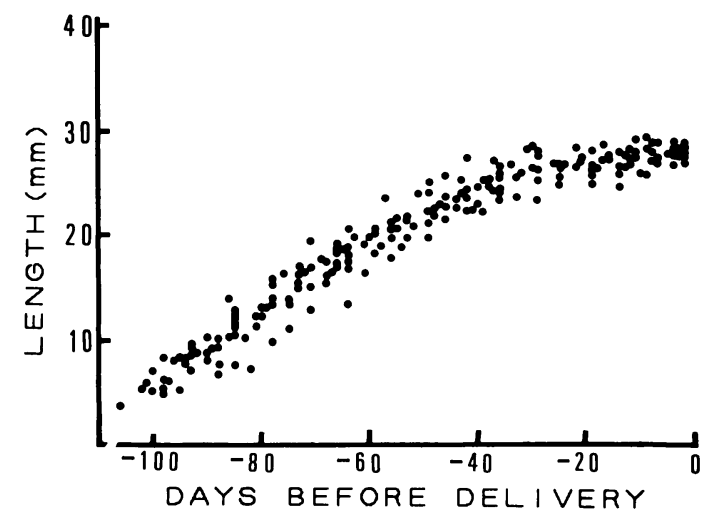

Fig. 6. Change of the fetal biparietal diameter according to number of day before delivery

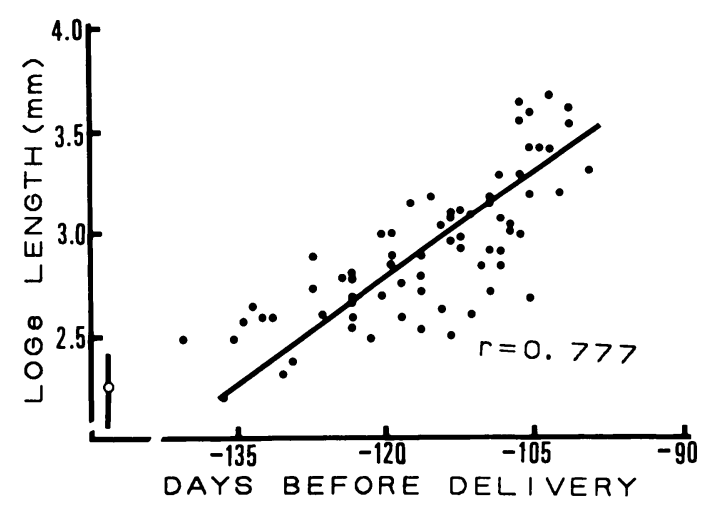

Fig. 7. Correlation between the natural logarithmic value of major axial length $(\mathrm{mm})$ of uterus and the number of day before delivery $(p<0.01)$ Mean with standard deviation for the lengths of non-pregnant uteri was represented in the figure.
降はほぼ一定の值を示すようになった。この計測值に対 数曲線をあてはめたとてろ相関係数は，0.904(p<0.01) と高度に有意となった（Fig．6)。また，子宮の長径及 び短径の変化は Figs 7,8 に示すように GS の長径及 び短径の変化と同じく分娩前日数と有意な相関が認めら れた。相関係数は長径では $0.777(\mathrm{p}<0.01)$ また, 短 径では0.754（p<0.01）であった。分娩前 135 日ごろに なると非妊娠時の子宮よりあ大きくなりはじめた。

また, 出生直前の胎仔の USD 法による計測值と, 同 じ動物の出生直後のノギスによる計測值を Table 1 に 示す。出生直後の計測值の方がわずかに大きな值が得ら れた。雌雄それぞれで測定値の差の検定を行ったところ 有意ではなかった（p>0.05）。

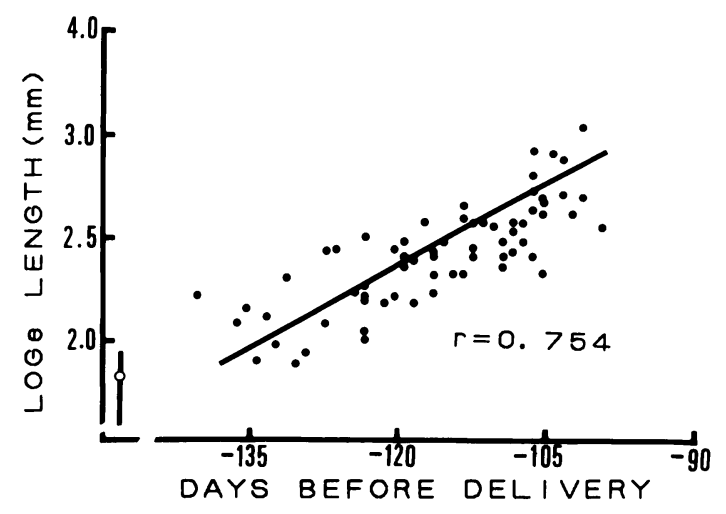

Fig. 8. Correlation between the natural logarithmic value of minor axial length $(\mathrm{mm})$ of uterus and the number of day before delivery $(p<0.01)$ Mean with standard deviation for the lengths of non-pregnant uteri was represented in the figure.

Table 1. Comparison of biparietal diameters (BPD) between the fetuses and the newborns

\begin{tabular}{lccc}
\hline Sex & $\begin{array}{c}\text { Number of } \\
\text { animals }\end{array}$ & \multicolumn{2}{c}{ BPD $(\mathrm{mm})$} \\
\hline Female & 4 & $28.6 \pm 0.6^{3)}$ & $29.6 \pm 1.4^{4)}$ \\
Male & 4 & $28.8 \pm 0.4$ & $30.1 \pm 1.6$ \\
\hline Total & 8 & $28.7 \pm 0.4$ & $29.8 \pm 1.6$ \\
\hline
\end{tabular}

1) $2.6 \pm 2.4$ days before delivery

2) on the day of birth

3) measured by USD

4) measured by biometrically with slide calipers 


\section{考察}

USD 法での画像の解像力は, 用いる超音波の周波数 に大きく影響される。我々はカニクイザルの場合 $5 \mathrm{MHz}$ の探触子を用いたが，今回のリスザルでの場合，それよ りあ解像力の優れた $7.5 \mathrm{MHz}$ の探触子を用いた。その 結果, リスザルで早期妊娠診断が可能であると判断した。 診断は子宮内の GS の存否の確認, さらにその後に観察 できる心拍動の確認によって行うことができた。ての方 法はカニクイザルで，すでに我々が行った報告之同じで ある[1]。リスザルで, GS の存在が初めて検出された 日の平均值は, 分婏前 127 日であった。乙の時期はカ二 クイザルで GS が確認される時期（胎齢20日, 平均妊娠 期間 165 日）よりやや遅い時期であった 1 ］。しかむ, リスザルの場合この時期の GS の存在の断定が困難な例 ああった。しかし,分婏前 114 日になると, GS の存在は 黒い画像として明らかに識別可能となる。以上のてとか ら, 我々は, リスザルの場合分娭前 114 日程度で妊娠䧐 断が可能であると判断している。娃娠にともない GS の 長径及び短径とも指数関数的に增大した。他方, BPD は妊娠の経過とともに, ほぼ直線的に増加したが, 分婏 前30日を過ぎたころからほぼ一定の值を示すようになっ た。したがって, 妊娠早期の胎仔の成長は, GS の変化 によって正確に評価でき, 妊娠中期加ら後期の胎仔の成 長は BPD の測定によって評価が可能である。また， BPD がほぼ一定の值を示すようになる時点からおよそ 1 力月後に出産するととが判明したため分娩予知も可能 となった。

ところで，USD による BPD の計測值の信頼性を見 るために, 同一個体で分婏近い時期（分娭前 2.6 日 \pm 2.4 日）之分娩後 24 時間以内での計測值の比較を行った。分 娩直前の USD に上る計測值は, 分娩後 24 時間以内に ノギスで測った値より僅か $1 \mathrm{~mm}$ 程度小さかった（Table 1)。乙の時期の計測日による差（出生日と出生前 3 日程 度）は BPD の成長速度加判断して, 無視しうると思 われる。とああれ，USD による BPD の測定值は十分 に信頼できると言える。

ところで，妊娠にとあなう子宮の大きさむ指数関数的 に增加した。計測值の自然対数值と分婏前日数との間の 直線回帰は高度に有意 $(\mathrm{p}<0.01)$ であった。

リスザルの妊娠期間は, 産地によって異なる可能性が 示唆されている[4]が，162 日[5]あるいは 155 日[ 3 ] という報告があり，お扰よそ 160 日前後と推定される。
ところで，USD 法を用いることによって分婏前 114 日 程度でリスザルの妊娠彭断が可能であるととが今回の成 績より明らかになったわけであるが，てのリスザルの妊 娠診断判定可能時期は, 前述の推定妊娠期間上り妊娠 6 ないし 7 週目ということになる。カニクイザルの妊娠診 断が USD 法により約 3 週目で可能である $[1]$ ととに 対し, リスザルの場合はそれよりも遅れるものの, 本法 によって比較的早期に妊娠診断が可能であるてとが明ら かとなった。さらにまた，ての方法によってリスザル胎 仔の成長過程の観察を容易に行うことができ, 妊張個体 や胎仔の健康管理に利用し得ることが示された。

\section{要 約}

実験用リスザルの妊娠診断と胎仔の発育観察の為の超 音波診断装置 (USD) の有用性について検討を加えた。 妊娠彭断は, 子宮内の胎のう (GS) の検出によって行っ たが，初めての検出日は分婏前127日 10 日草あっった。 さらに，分婏前 114 日ごろには胎仔心拍動む確認された。 また, GS の長径及び短径, 胎仔の頭部大横径 (BPD) の計測により胎仔の発育を観察した。妊娠子宮が非妊娠 子宮より大きくなったてとが検知できる時期は，分婏前 135 日ごろであった。

\section{文献}

［1］長 文昭・成田勇人・小野孝浩・本庄重男 (1987)，超音 波猃断装置によるカニクイザルの早期妊娠診断と胎仔の発 青観察, 実験動物, 36, 223-228.

[2] Honjo, S., Fujiwara, T., and Cho, F. (1975). A comparison of breeding performance of individual cage and indoor gang cage systems in cynomolgus monkeys. In Contemporary Primatology (ed. by S. Kondo, M. Kawai and A. Ehara). pp. 98-105. S. Karger, AG. Basel, Switzerland.

[3] Jarosz, S. J., Kuehl, T. J., and Dukelow, W. R. (1977). Vaginal cytology, induced ovulation and gestation in the squirrel monkey (Saimiri sciureus). Biol. Reprod., 16, 97-103.

[4] Kerber, W.T., Conaway, C. H., and Smith, D. M. (1977). The duration of gestation in the squirrel monkey (Saimiri sciureus). Lab. Anim. Sci., 27, 700-702.

[ 5 ] Lorenz, R., Anderson, C. O., and Mason, W. A. (1973). Notes on reproduction in captive squirrel monkeys (Saimiri sciureus). Folia Primatol. (Basel), 19, 286-292.

[6] Yoshida, T., Suzuki, K., Cho, F., and Honjo, S. (1987). Serum chorionic gonadotropin levels determined by radioreceptorassay and early diagnosis of pregnancy in the cynomolgus monkey (Macaca fascicularis). Am. J. Primatol., 12, 101106. 